\title{
Review Article \\ Comprehensive Review on Betulin as a Potent Anticancer Agent
}

\author{
Sylwia Katarzyna Król, ${ }^{1}$ Michał Kiełbus, ${ }^{1}$ Adolfo Rivero-Müller, ${ }^{1,2,3}$ and Andrzej Stepulak ${ }^{1,4}$ \\ ${ }^{1}$ The Chair and Department of Biochemistry and Molecular Biology, Medical University, 20-093 Lublin, Poland \\ ${ }^{2}$ Department of Physiology, Institute of Biomedicine, University of Turku, 20520 Turku, Finland \\ ${ }^{3}$ Faculty of Natural Sciences and Technology, Åbo Akademi University, 20500 Turku, Finland \\ ${ }^{4}$ Department of Otolaryngology, MSW Hospital, 20-331 Lublin, Poland
}

Correspondence should be addressed to Sylwia Katarzyna Król; sylwia_krol15@wp.pl

Received 20 June 2014; Accepted 11 August 2014

Academic Editor: Yih-Shou Hsieh

Copyright (C) 2015 Sylwia Katarzyna Król et al. This is an open access article distributed under the Creative Commons Attribution License, which permits unrestricted use, distribution, and reproduction in any medium, provided the original work is properly cited.

\begin{abstract}
Numerous plant-derived substances, and their derivatives, are effective antitumour and chemopreventive agents. Yet, there are also a plethora of tumour types that do not respond, or become resistant, to these natural substances. This requires the discovery of new active compounds. Betulin (BE) is a pentacyclic triterpene and secondary metabolite of plants abundantly found in the outer bark of the birch tree Betulaceae sp. BE displays a broad spectrum of biological and pharmacological properties, among which the anticancer and chemopreventive activity attract most of the attention. In this vein, BE and its natural and synthetic derivatives act specifically on cancer cells with low cytotoxicity towards normal cells. Although the antineoplastic mechanism of action of BE is not well understood yet, several interesting aspects of BE's interactions are coming to light. This review will summarize the anticancer and chemopreventive potential of $\mathrm{BE}$ in vitro and in vivo by carefully dissecting and comparing the doses and tumour lines used in previous studies, as well as focusing on mechanisms underlying its activity at cellular and molecular level, and discuss future prospects.
\end{abstract}

\section{Introduction}

Epidemiological data indicated an increase in the cancer incidence and mortality. According to the GLOBOCAN 2008 estimations, there have approximately been 12.7 million new cancer cases diagnosed and 7.6 million deaths worldwide in 2008 [1]. Furthermore, it has been also prognosed that cancer will exceed heart diseases as the leading cause of death in the world, entailing serious social and economic consequences [2]. Despite the significant development of new surgical techniques, radio-, chemo-, and targeted therapy, failures in tumour treatment are still the most important challenges to oncology [3]. The current radio- and chemotherapy procedures also result in the damage of normal cells and consequently cause a number of serious side effects. Additionally, the acquired drug resistance by tumour cells is considered to be responsible for the failure of conventional types of oncological therapy, including cytostatic drugs and radiation [4]. A novel approach to the cancer treatment has appreciated the key components of specifically altered signalling pathways in neoplastic cells or targeting of the tumour microenvironment without affecting noncancerous cells.

The use of natural plant-derived compounds has been considered to be an interesting aspect for the treatment of human neoplastic diseases. Natural plant-derived substances, relatively easily available due to their commonly occurrence in the nature, seem to constitute a promising group of anticancer or chemopreventive agents and have played a key role in the development of drugs or supplements for the treatment of several human cancers. Of all commercially offered anticancer drugs between 1981 and 2006, no more than $22.2 \%$ of the total number have been categorized as synthetic ones [5-7].

The most applicable anticancer drugs derived from plants being in clinical use are taxanes (including paclitaxel isolated from Taxus brevifolia Nutt., Taxaceae) [8] and vinca alkaloids (Catharanthus alkaloids) (including vinblastine and 


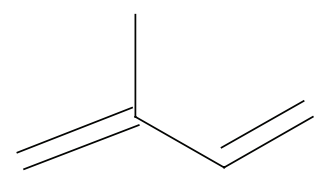

FIgURE 1: Chemical structure of isoprene.

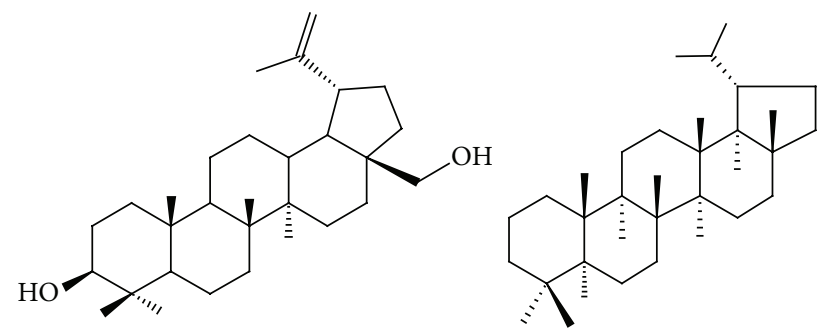

Figure 2: Chemical structure of betulin and lupane.

vincristine, isolated from Catharanthus roseus (L.) G. Don, Apocynaceae) [9]. Moreover, many derivatives of these substances have been synthesized.

Terpenes are a large group of widespread secondary metabolites of plants and are considered as potentially useful in cancer pharmacotherapy, because of their selective cytotoxicity towards numerous human cancer cells, as demonstrated in vitro and in vivo studies. Triterpenes, one of terpenes classes, are formed from six isoprene units (Figure 1) and occur as complex cyclic structures called triterpenoids [10].

Betulin (BE, 3-lup-20(29)-ene-3 $\beta$,28-diol), also known as betulinol, betuline, or betulinic alcohol [11], is a pentacyclic lupane-type triterpenoid (Figure 2) naturally distributed in many plants $[12,13]$. BE was one of the first natural substances isolated from plants, by Lowitz in 1788, and its chemical structure was finally determined in 1952. Later, BE has been found in other plant species of the Betulaceae family, as a component of the outer bark of the birch species, Betula alba, B. pendula, B. pubescent, and B. platyphylla. BE has also been found in Diospyros leucomelas, Zizyphus mauritiana, Nelumbo nucifera, seeds of Ziziphus vulgaris var. spinosus, and in the bark of Trochodendron aralioides. BE is predominantly found in a content between 10 and 30\% [14], through 34\% of dry weight of bark from white birch [15] or even over $50 \%$ in the birch bark extract from $B$. pendula Roth [16] and yellow birch (B. alleghaniensis Britton) in the Quebec region in Canada [17]. Chemical composition of the birch bark extracts is strongly linked to preparation and purification methods used and influences the percentage of $\mathrm{BE}$ which can vary from $54 \%$ to $82 \%$ of dry weight [16].

Numerous studies have demonstrated that BE elicits a broad range of biological and pharmacological properties, including antibacterial, antifungal, and antiviral activities. However, the anticancer and chemopreventive potential of $\mathrm{BE}$ are the focus of most attention [11].

\section{BE Inhibits Proliferation and Invasion of Different Types of Cancer}

$\mathrm{BE}$ has been shown to elicit anticancer properties by inhibiting cancer cells growth. Cytotoxicity and antiproliferative potential of $\mathrm{BE}$ have been studied in several established cancer cell lines, as well as primary tumour cell cultures (Tables 1 and 2 and references therein) and cancer xenograft models.

Furthermore, there are some data reporting antitumour potential of tropical plants-derived BE, suggesting that Betulaceae species may not be the only origin of biologically and pharmacologically active BE. It is considered that BE elicits antiproliferative and cytotoxic activity irrespectively of the natural source. BE isolated from Chaenomeles sinensis KOEHNE has had an inhibitory effect (with the $\mathrm{IC}_{50}$ $20.9 \mu \mathrm{M})$ on soft agar colony formation induced by TPA (12$O$-tetradecanoyl phorbol-13 acetate) in mouse epidermal cells (JB6 Cl 22, Cl 41 cells) [18], whereas BE from the twigs of Celtis philippinensis inhibited proliferation of lung cancer cells [19], and $\mathrm{BE}$ from the roots of Belamcanda chinensis (L.) DC was effective against breast, prostate, and stomach cancer cells [20]. Likewise, BE from the twigs of Coussarea paniculata decreased proliferation of human ovarian carcinoma cells [21], whereas BE from Cyrtomium fortumei (J.) inhibited growth of human prostate and stomach cancer cell lines [22].

$\mathrm{BE}$ has exhibited quite a different range of its antiproliferative activity, depending on cancer cells type, from a weak inhibition of cell proliferation in human erythroleukaemia cell line (K562) to a strong inhibition in human neuroblastoma cells (SK-N-AS), where the effect has been most pronounced (Table 1 and references therein). Additionally, $\mathrm{BE}$ has also been found to express significant cytotoxicity against primary cancer cells cultures isolated from tumour samples obtained from ovarian, cervical carcinoma, and glioblastoma patients, where the $\mathrm{IC}_{50}$ values have ranged from 2.8 to $3.4 \mu \mathrm{M}$ [23] (Table 2), being significantly lower, when compared with established cell lines [21, 24].

Other studies have shown clearly pronounced effect of BE towards human neural tumour cell lines with the $\mathrm{IC}_{50}$ value $10.3 \mu \mathrm{M}$ in TE671 (rhabdomyosarcoma/medulloblastoma), neuroblastoma cells-2.5 $\mu \mathrm{M}$ in SK-N-AS [23], 17.1 $\mu \mathrm{M}$ in GOTO, and $16.5 \mu \mathrm{M}$ in NB-1 cell line [25], and glial tumour$5.9 \mu \mathrm{M}$ in C6 (rat glioma) [23].

It should be mentioned that $\mathrm{BE}$ has also elicited significant antiproliferative potential against human thyroid carcinoma FTC 238 cells and the concentration $6.8 \mu \mathrm{M}$ has effectively inhibited proliferation of $50 \%$ cells after $48 \mathrm{~h}$ treatment [23].

$\mathrm{BE}$ has been investigated for its anticancer potential in human lung cancer cells Lul (with the $\mathrm{IC}_{50}$ values $>45.2 \mu \mathrm{M}$ ) [19], NCI-H460 (nonsmall cell lung carcinoma, the $\mathrm{IC}_{50}$ value $63.5 \mu \mathrm{M})$ [26], and A549. Interestingly, A549 cell line has been extensively studied by several authors, and the $\mathrm{IC}_{50}$ values have prominently ranged from $3.8 \mu \mathrm{M}[27,28]$ through $7.4 \mu \mathrm{M}$ [23] and $20 \mu \mathrm{M}$ [29] to $33.4 \mu \mathrm{M}$ [26]. Another study has shown that the dose of $\mathrm{BE}$ required to reach a $10 \%$ cell viability inhibition $\left(\mathrm{ID}_{10}\right)$ in $\mathrm{A} 549$ cells has been $0.7 \mu \mathrm{M}$ and the effect obtained after $24 \mathrm{~h}$ has been nearly doubled, 
TABLE 1: In vitro antiproliferative effect of $\mathrm{BE}$ on human and animal cancer cell lines by means of $\mathrm{IC}_{50}$ values (inhibitory concentration $50 \%$ ).

\begin{tabular}{|c|c|c|c|c|}
\hline \multirow{2}{*}{ Cancer type } & \multirow{2}{*}{ Cell line } & \multicolumn{2}{|c|}{$\mathrm{IC}_{50}$} & \multirow{2}{*}{ References } \\
\hline & & $\mu \mathrm{M}$ & $\mu \mathrm{g} / \mathrm{mL}$ & \\
\hline \multirow{3}{*}{ Human myelogenous leukaemia } & \multirow{3}{*}{ K562 } & 14.5 & 6.4 & {$[25]$} \\
\hline & & $>225.9$ & $>100.0$ & {$[26]$} \\
\hline & & $>250.0$ & $>111.0$ & {$[35]$} \\
\hline Human neuroblastoma & SK-N-AS & 2.5 & 1.1 & \multirow{2}{*}[23]{} \\
\hline Human rhabdomyosarcoma/medulloblastoma & TE671 & 10.3 & 4.6 & \\
\hline Human neuroblastoma & GOTO & 17.1 & 7.6 & \multirow{2}{*}[25]{} \\
\hline Human neuroblastoma & NB-1 & 16.5 & 7.3 & \\
\hline Rat glioma & $\mathrm{C} 6$ & 5.9 & 2.6 & \multirow{2}{*}[23]{} \\
\hline Human thyroid carcinoma & FTC 238 & 6.8 & 3.0 & \\
\hline Human lung cancer & Lul & $>45.2$ & $>20.0$ & {$[19]$} \\
\hline Human nonsmall cell lung carcinoma & NCI-H460 & 63.5 & 28.1 & {$[26]$} \\
\hline \multirow{4}{*}{ Human lung carcinoma } & \multirow{4}{*}{ A549 } & 20.0 & 8.9 & {$[29]$} \\
\hline & & 33.4 & 14.8 & {$[26]$} \\
\hline & & 7.4 & 3.3 & {$[23]$} \\
\hline & & 3.8 & 1.7 & \multirow{2}{*}[27,28]{} \\
\hline \multirow{3}{*}{ Human breast adenocarcinoma } & \multirow{3}{*}{ MCF-7 } & 23.3 & 10.3 & \\
\hline & & 30.7 & 13.6 & {$[26]$} \\
\hline & & 8.32 & 3.7 & {$[32]$} \\
\hline \multirow{2}{*}{ Human breast carcinoma } & \multirow{2}{*}{ T47D } & 5.2 & 2.3 & {$[23]$} \\
\hline & & 73.2 & 32.4 & {$[33]$} \\
\hline \multirow{5}{*}{ Human cervical carcinoma } & \multirow{5}{*}{ HeLa } & 74.1 & 32.8 & $24 \mathrm{~h}[24]$ \\
\hline & & 57.1 & 25.3 & $48 \mathrm{~h}[24]$ \\
\hline & & 34.4 & 15.2 & $72 \mathrm{~h}[24]$ \\
\hline & & 22.6 & 10.0 & {$[26]$} \\
\hline & & 6.7 & 2.9 & {$[32]$} \\
\hline Human ovarian carcinoma cells & A2780 & $>45.2$ & $>20.0$ & {$[21]$} \\
\hline \multirow{2}{*}{ Human prostate adenocarcinoma } & \multirow{2}{*}{ PC-3 } & 17.9 & 7.9 & {$[27,28]$} \\
\hline & & 82.9 & 36.7 & {$[26]$} \\
\hline Hormone-dependent human prostate cancer & LNCaP & $>45.2$ & $>20.0$ & {$[19]$} \\
\hline Human gastric carcinoma & EPG85-257P & 18.7 & 8.3 & \multirow{2}{*}[36]{} \\
\hline Human pancreatic carcinoma & EPP85-181P & 21.1 & 9.3 & \\
\hline Human colorectal adenocarcinoma & DLD-1 & 6.6 & 2.9 & {$[27,28]$} \\
\hline Human colorectal adenocarcinoma & HT-29 & 4.3 & 1.9 & {$[23]$} \\
\hline Human colon cancer & $\mathrm{Col} 2$ & 45.2 & $>20.0$ & {$[19]$} \\
\hline Human colorectal adenocarcinoma & SW707 & 51.7 & 22.9 & {$[33]$} \\
\hline Human hepatoma & HepG2 & 22.8 & 10.1 & \multirow{2}{*}{ [26] } \\
\hline Human hepatocarcinoma & SK-HEP-1 & 132.1 & 58.5 & \\
\hline Human melanoma & G361 & 12.4 & 5.5 & \\
\hline Human melanoma & SK-MEL-28 & 16.2 & 7.2 & {$[25]$} \\
\hline Mouse melanoma & B16-F1 & 13.8 & 6.1 & {$[27]$} \\
\hline Mouse melanoma & B16 2F2 & 27.4 & 12.1 & {$[37]$} \\
\hline Human melanoma & MEL-2 & $>45.2$ & $>\mathbf{2 0 . 0}$ & {$[38]$} \\
\hline Human melanoma & SK-MEL2 & $>250.0$ & $>111.0$ & {$[35]$} \\
\hline Human skin epidermoid carcinoma & A431 & 6.8 & 3.0 & {$[32]$} \\
\hline Human promyeloblastic leukaemia & HL60 & 14.7 & 6.5 & \\
\hline Human leukaemia & U937 & 14.4 & 6.4 & {$[25]$} \\
\hline Human T lymphoblast leukaemia & Jurkat E6.1 & 6.7 & 3.0 & {$[23]$} \\
\hline
\end{tabular}


TABLe 1: Continued.

\begin{tabular}{|c|c|c|c|c|}
\hline \multirow{2}{*}{ Cancer type } & \multirow{2}{*}{ Cell line } & \multicolumn{2}{|c|}{$\mathrm{IC}_{50}$} & \multirow{2}{*}{ References } \\
\hline & & $\mu \mathrm{M}$ & $\mu \mathrm{g} / \mathrm{mL}$ & \\
\hline Mouse leukaemia & P388 & 12.4 & 5.5 & \multirow{2}{*}{ [33] } \\
\hline Human leukaemia & CCRF/CEM & 24.6 & 10.9 & \\
\hline Human multiple myeloma & RPMI 8226 & 6.4 & 2.8 & [23] \\
\hline Human oral epidermoid carcinoma & $\mathrm{KB}$ & $>45.2$ & $>20.0$ & {$[19]$} \\
\hline Gastric carcinoma, atypical mitoxantrone MDR variant & EPG85-257RNOV & 12.3 & 5.4 & \multirow{4}{*}{ [36] } \\
\hline Gastric carcinoma, classical daunorubicin MDR variant & EPG85-257RDB & 11.0 & 4.9 & \\
\hline Pancreatic carcinoma, atypical mitoxantrone MDR variant & EPP85-181RNOV & 20.6 & 9.1 & \\
\hline Pancreatic carcinoma, classical daunorubicin MDR variant & EPP85-181RDB & 26.5 & 11.7 & \\
\hline Human myelogenous leukaemia (paclitaxel-resistant) & K562-Tax & 250.0 & 111.0 & [35] \\
\hline
\end{tabular}

To facilitate comparison, the doses were recalculated to $\mu \mathrm{M}$ or $\mu \mathrm{g} / \mathrm{mL}$. Original data are presented in bold.

TABLE 2: In vitro antiproliferative effect of BE on human tumour primary cultures by means of $\mathrm{IC}_{50}$ values (inhibitory concentration $50 \%$ ).

\begin{tabular}{lcccc}
\hline Tumour type & Primary culture & $\mu \mathrm{M}$ & $\mathrm{IC}_{50}$ & $\mu \mathrm{g} / \mathrm{mL}$ \\
\hline Ovarian carcinoma & HPOC & $\mathbf{2 . 8}$ & 1.2 & References \\
Cervical carcinoma & HPCC & $\mathbf{3 . 4}$ & 1.5 & 1.5 \\
Glioblastoma multiforme & HPGBM & $\mathbf{3 . 4}$ & {$[23]$} \\
\hline
\end{tabular}

To facilitate comparison, the doses were recalculated to $\mu \mathrm{M}$ or $\mu \mathrm{g} / \mathrm{mL}$. Original data are presented in bold.

when the treatment has been extended to $48 \mathrm{~h}(0.4 \mu \mathrm{M})$ [30]. Moreover, $\mathrm{BE}$ has also been found to be slightly more potent antitumour agent than cisplatin $\left(\mathrm{IC}_{50}\right.$ value $\left.25 \mu \mathrm{M}\right)$ towards human lung cancer A549 cell line [29], however, was also demonstrated to be inactive towards nonsmall-cell bronchopulmonary carcinoma (NSCLC-N6) [31].

$\mathrm{BE}$ has also been evaluated in vitro for its anticancer potential towards the most commonly diagnosed cancers in women worldwide [1]. Its inhibitory effect on the growth of human breast, cervical, and ovarian carcinoma cells has been shown. Cell proliferation was $53.2 \%$ inhibited by $20 \mu \mathrm{M}$ of BE in MCF-7 and Bcap-37 cell lines (both breast cancer cell lines) [20]. Other studies have shown that $\mathrm{BE}$ at the concentration $10 \mu \mathrm{M}(4.43 \mu \mathrm{g} / \mathrm{mL})$ and $30 \mu \mathrm{M}(13.28 \mu \mathrm{g} / \mathrm{mL})$ inhibited $25.81 \%$ and $35.54 \%$ proliferation of MCF-7 cells, respectively [16], whereas another report has shown the $\mathrm{IC}_{50}$ value $-8.32 \mu \mathrm{M}$ [32]. Significantly higher $\mathrm{IC}_{50}$ values for MCF-7 cells have been reported in several other studies$23.3 \mu \mathrm{M}[27,28]$ and $30.7 \mu \mathrm{M}$ [26]. T47D cell line has varied significantly in the sensitivity to the antiproliferative properties of $\mathrm{BE}$ with the $\mathrm{IC}_{50}$ value from $5.2 \mu \mathrm{M}$ [23] to $73.2 \mu \mathrm{M}$ [33]. On the other side, $\mathrm{BE}$ has been shown to elicit about three-fold weaker antiproliferative activity $\left(\mathrm{IC}_{50}\right.$ value $17 \mu \mathrm{M}$ ) with respect to cytostatic agent 5-fluorouracil (5-FU, with the $\mathrm{IC}_{50}$ value $5.34 \mu \mathrm{M}$ ) against MCF-7 cell line [34]. The proliferation of human cervical cancer cells (HeLa cell line) has been inhibited in dose- and time-dependent manner. The $\mathrm{IC}_{50}$ values after $24 \mathrm{~h}$ were $74.1 \mu \mathrm{M}$ [24], after $48 \mathrm{~h} 22.6 \mu \mathrm{M}$ [26] and $57.1 \mu \mathrm{M}$ [24], and $6.67 \mu \mathrm{M}$ [32] and $34.4 \mu \mathrm{M}[24]$ after $72 \mathrm{~h}$. The dose required to reach an $\mathrm{ID}_{10}$ in HeLa has been $0.47 \mu \mathrm{M}$, and the effect obtained after $24 \mathrm{~h}$ has been significantly enhanced when the treatment has been extended to $48 \mathrm{~h}(0.32 \mu \mathrm{M})$ [30]. Other authors have reported
$\mathrm{BE}$ to inhibit proliferation of HeLa cells at the concentration $10 \mu \mathrm{M}(4.43 \mu \mathrm{g} / \mathrm{mL})$ and $30 \mu \mathrm{M}(13.28 \mu \mathrm{g} / \mathrm{mL})$ by $73.02 \%$ and $81.39 \%$, respectively [16]. BE at the concentration $>45.2 \mu \mathrm{M}$ has been demonstrated to reach a $50 \%$ cell proliferation inhibition in human ovarian carcinoma cells (A2780 cell line) [21].

Furthermore, some studies have also provided evidence that $\mathrm{BE}$ elicits antiproliferative activity towards human prostate cancers including androgen-dependent type. However, high discrepancies appear when comparing the $\mathrm{IC}_{50}$ values towards the same cell line PC-3, ranging from $17.9 \mu \mathrm{M}$ [27, 28] through $82.9 \mu \mathrm{M}$ [26] up to $>250 \mu \mathrm{M}$ [35]. For example, BE inhibited proliferation of PC-3 cells by $18.4 \%$ [22] and by $17.3 \%$ at concentration $20 \mu \mathrm{M}$ [20], whereas in LNCaP cells (androgen-dependent human prostate cancer cell line) the $\mathrm{IC}_{50}$ was over $45.2 \mu \mathrm{M}$ [19].

$\mathrm{BE}$ has also been shown to display antiproliferative activity towards cancers within human digestive system. BE has inhibited proliferation by $50 \%$ in pancreatic carcinoma (EPP85-181) and human gastric (EPG85-257) cell lines at $21.09 \mu \mathrm{M}$ and $18.74 \mu \mathrm{M}$ concentration, respectively [36]. The proliferation of another stomach cancer cell line (MGC-803) was inhibited by $43.7 \%$ [20] and $45.1 \%$ [22] at a concentration of $20 \mu \mathrm{M}$. BE has been investigated for its antiproliferative potential towards human colorectal adenocarcinomas, DLD1, HT-29, Col2, and SW707 cells. Inhibition of cells proliferation in response to $\mathrm{BE}$ has been highly dependent on the cell line. The $\mathrm{BE} \mathrm{IC}_{50}$ values for DLD-1 $[27,28]$ and HT-29 colon cancer cells [23] have been comparable, $6.6 \mu \mathrm{M}$ and $4.3 \mu \mathrm{M}$, respectively, and considerably much lower than for Col2 cells, with the $\mathrm{IC}_{50}$ values of $45.2 \mu \mathrm{M}$ [19], and for SW707 cells$51.7 \mu \mathrm{M}$ [33]. Conversely, BE is ineffective against HT-29 cells, with an $\mathrm{IC}_{50}$ value higher than $250 \mu \mathrm{M}$ [35]. 
BE has also demonstrated extremely diverse antiproliferative effects on human hepatoma cell lines. The $\mathrm{IC}_{50}$ values have ranged from $22.8 \mu \mathrm{M}$ in HepG2 cells to $132.1 \mu \mathrm{M}$ in SK-HEP-1 cells [26]. The BE dose required to reach an $\mathrm{ID}_{10}$ in HepG2 has been $1.02 \mu \mathrm{M}$, and the antiproliferative effect obtained after $24 \mathrm{~h}$ has been almost doubled after the treatment time has been extended to $48 \mathrm{~h}(0.5 \mu \mathrm{M})$ [30].

Moreover, $\mathrm{BE}$ has been tested with promising results for its cytotoxicity and inhibitory activity towards a series of melanoma cell lines. The $\mathrm{BE} \mathrm{IC}_{50}$ values in human melanoma cells G361 and SK-MEL-28 have been comparable, $12.4 \mu \mathrm{M}$ and $16.2 \mu \mathrm{M}$, respectively [25], similar to those for murine melanoma B16-F1 cells-13.8 $\mu \mathrm{M}$ [27], but considerably lower than in the case of B16 2F2 [37] and MEL-2 [38] cell lines, suggesting that antiproliferative potential of $\mathrm{BE}$ was independent from the cells origin (of human or non-human origin). Similarly, BE (at a concentration $10 \mu \mathrm{M}$ ) demonstrated a marked decrease in viability of other murine melanoma, B164A5 cell line, resulting in a 52\% reduction of viable cells compared to control [39], while it has moderate activity towards epidermoid carcinoma of the mouth $\mathrm{KB}$ cells $\left(\mathrm{IC}_{50}\right.$ value $>45.2 \mu \mathrm{M}$ ) [38] and total inactivity towards melanoma SK-MEL2 cells with an $\mathrm{IC}_{50}$ value higher than $250 \mu \mathrm{M}$ [35]. Another skin cancer epidermoid carcinoma A431 cell line was much more sensitive to $\mathrm{BE}$ treatment; the concentrations $10 \mu \mathrm{M}(4.43 \mu \mathrm{g} / \mathrm{mL})$ and $30 \mu \mathrm{M}(13.28 \mu \mathrm{g} / \mathrm{mL})$ have inhibited proliferation by $63.42 \%$ and $70.30 \%$, respectively [16], and the $\mathrm{IC}_{50}$ value was $6.76 \mu \mathrm{M}[32]$.

Cytotoxicity and antiproliferative activity of $\mathrm{BE}$ have also been confirmed towards a panel of human and murine haematological malignancies in vitro. $\mathrm{BE}$ has significantly suppressed cells growth in several models of leukaemia, HL60 and U937 cell lines [25], with the comparable $\mathrm{IC}_{50}$ values 14.7 and $14.4 \mu \mathrm{M}$, respectively, but the most pronounced effect has been observed in Jurkat E6.1 cells-6.7 $\mu \mathrm{M}$ [23]. Nearly two-fold weaker activity of BE towards human leukaemia CCRF/CEM cells versus mouse leukaemia P388 cell line has been observed (IC50 24.6 versus $12.4 \mu \mathrm{M}$ ) [33]. Although this results have been contested by other studies that show a total lack of BE activity against CEM cellsIC $_{50}$ value $>250 \mu \mathrm{M}[35,40,41]$. Similar discrepancies have been demonstrated towards human chronic myelogenous leukaemia $\mathrm{K} 562$ whereas on one hand $\mathrm{BE}$ is reported as active, $\mathrm{IC}_{50}$ value $14.5 \mu \mathrm{M}$ [25], while on the other hand it is completely inactive, $\mathrm{IC}_{50}$ values $>200 \mu \mathrm{M}$ [26] and $250 \mu \mathrm{M}$ [35]. Additional studies have evidenced notable activity of $\mathrm{BE}$ in human multiple myeloma RPMI 8226 cell line, where the concentration $6.4 \mu \mathrm{M}$ inhibited growth of $50 \%$ cells after $48 \mathrm{~h}$ treatment [23].

The significant discrepancies between $\mathrm{IC}_{50}$ doses of $\mathrm{BE}$ towards the same cell lines, A549 [23, 26-29], T47D [23, 33], PC-3 [26-28, 35], CCRF/CEM [33, 35, 40, 41], and K562 $[25,26,35]$, evaluated by different authors seem to be the result of various sources of $\mathrm{BE}$ and extraction procedures as well as lack of standardised treatment modalities (treatment times, doses, and individual features of each laboratory cell strains).

Conspicuously, BE shows antiproliferative and cytotoxic activity towards cancer cell lines resistant to conventional cytostatic drugs, which suggests a novel mechanism of action. BE has been shown to elicit significantly stronger antiproliferative effect (by means of $\mathrm{IC}_{50}$ ) values on the daunorubicin- and mitoxantrone-resistant cancer cells, such as the DB-resistant human gastric cancer 257RDB cell line ( $\mathrm{IC}_{50} 10.97 \mu \mathrm{M}$ ), and NOV-resistant (Novantrone) human gastric cancer 257RNOV cell line ( $\mathrm{IC}_{50} 12.25 \mu \mathrm{M}$ ), and human pancreatic carcinoma 181RNOV cell lines ( $\mathrm{IC}_{50} 20.62 \mu \mathrm{M}$ ) than on the drug-sensitive parental 257P and 181P cells [36], whereas BE has been inactive towards K562-Tax (paclitaxelresistant subline of human chronic myelogenous leukaemia), with the IC50 value $>250 \mu \mathrm{M}$ [35]. Nevertheless, BE has been suggested to overcome some forms of drug resistance in cancer cells refractory to conventional chemotherapeutic agents [36].

The purity and purification methods play important roles in the downstream activity of $\mathrm{BE}$ and its derivatives. A growing body of evidence suggests that different $\mathrm{BE}$ extracts have better therapeutic potential than pure BE. In some cases, isolated $\mathrm{BE}$ has been found to elicit a weaker antiproliferative activity against the human gastric cell line (EPG85-257P) (Table 1) as compared with a crude birch bark extract, while in other cases, stronger inhibitory effect towards pancreatic carcinoma cells (EPP85-181P) by isolated BE as compared to the birch bark extract has been observed [36]. The outer bark of the birch trees contains $\mathrm{BE}$ as the main component but some other pentacyclic triterpenes as well [42]. Thereby, the synergistic effects of combination of various triterpenes with diverse activities and modes of action could explain to some extent the discrepancies in results obtained in vitro between birch bark extract and purified BE. Although this action, or combination of actions, is cell type-dependent, for example, a crude birch bark extract (B. pendula Roth, syn. B. verrucosa-European White Birch) has been found to elicit more pronounced antiproliferative potential against the daunorubicin- and mitoxantrone-resistant human gastric and pancreatic carcinoma cell lines $\left(\mathrm{IC}_{50}\right.$ values $4.29-7.08 \mu \mathrm{M}$ and 9.07-23.03 $\mu \mathrm{M}$, resp.), compared to the drug-sensitive parental 257P and 181P cell lines [36]. Likewise, the BEenriched (approximately 97\%) birch bark extract (B. pendula Roth) has shown strong antiproliferative potential towards human cancer cell lines A431, A2780, HeLa, and MCF7 in vitro, with the $\mathrm{IC}_{50}$ values from $2.26 \mu \mathrm{M}$ up to $11.29 \mu \mathrm{M}$ (1 and $5 \mu \mathrm{g} / \mathrm{mL}$ ) [43]. In another study, bark extract from B. pendula Roth with content of $57.01 \%$ of $\mathrm{BE}$ at the concentration of $17.53 \mu \mathrm{M}(7.76 \mu \mathrm{g} / \mathrm{mL})$ and $52.61 \mu \mathrm{M}(23.29 \mu \mathrm{g} / \mathrm{mL})$ has inhibited proliferation of A 431 (by $70.02 \%$ and $78.70 \%$, resp.), MCF-7 (by $45.54 \%$ and $55.55 \%$, resp.), and HeLa (by $70.62 \%$ and $76.23 \%$, resp.) cells stronger than pure BE [16]. A highly purified triterpene extract (TE) from the Betulae cortex with $\mathrm{BE}$ as a main component (up to $87.3 \% \mathrm{w} / \mathrm{w}$ of identified triterpenes) demonstrated a dose-dependent cytotoxicity from $0.090 \mu \mathrm{M}(0.04 \mu \mathrm{g} / \mathrm{mL})$ to $90.35 \mu \mathrm{M}(40 \mu \mathrm{g} / \mathrm{mL})$ in human nonmalignant, immortalized keratinocytes (HaCaT) and skin cancer A431 (squamous cell carcinoma) cell lines, similar to its main constituents, BE and betulinic acid (BA). TE has been shown to form an oleogel, which facilitates an application on the skin for dermatological indications [44]. 
An essential advantage of the use of $\mathrm{BE}$ as bioactive agent is its relatively low toxicity towards noncancerous cells [45]. BE has shown relatively modest cytotoxicity against human skin fibroblasts (HSF) - doses below $10 \mu \mathrm{M}$ have no apparent toxicity [23] — and mouse fibroblasts (Balb3T3) $\mathrm{IC}_{50}$ value $106.8 \mu \mathrm{M}(47.3 \mu \mathrm{g} / \mathrm{mL})[33]$. Also, BE has expressed low activity towards immortalized human epithelial cells (hTERT-RPElcell line) and human umbilical vein endothelial cells (HUVEC) with the $\mathrm{IC}_{50}$ values $>45 \mu \mathrm{M}(20 \mu \mathrm{g} / \mathrm{mL})$ [19]. $\mathrm{BE}$ isolated from the tropical plant Cyrtomium fortumei (J.) or $\mathrm{BE}$ from the roots of Belamcanda chinensis (L.) DC inhibited the growth of NIH3T3 mouse fibroblasts only by $29.8 \%$ and $33.5 \%$, respectively, at a concentration $20 \mu \mathrm{M}[20,22]$.

On the other hand, BE has shown significant antiproliferative effect against human normal skin fibroblasts (WS1), with the $\mathrm{IC}_{50}$ value $3.6 \mu \mathrm{M}[27,28]$ and normal lung fibroblasts $\mathrm{WI} 38\left(\mathrm{IC}_{50} 15.2 \mu \mathrm{M}\right)$ [25]. Although there are only few reports concerning BE influence on normal cells, noncancerous cells of various origins have been confirmed to be more resistant to BE treatment than tumour cells pointing to some cell-type selectivity. These encouraging results of in vitro studies make $\mathrm{BE}$ a promising therapeutic candidate.

$\mathrm{BE}$ has been shown to markedly impede the migration of several cancer cell types, including lung (lung carcinoma A549 cells) and central nervous system tumours (cell lines C6-glioma and TE671-rhabdomyosarcoma/medulloblastoma) [23].

In vivo antiangiogenic effects have also been reported for BE. Using the chorioallantoic membrane (CAM) model in chicken embryos, to study blood vessel formation, the antiangiogenic activity of BE has been proved by inhibition of the formation of new capillaries, presumably throughout targeting the endothelial cells [43]. This activity can be further enhanced by using $\mathrm{BE}$ in nanoemulsion formulation to increase penetrability to extraembryonic tissues [46]. Similarly, the decrease in melanoma tumour size in C57BL/6J mice model (at post-B164A5 tumour cells inoculation) after $\mathrm{BE}$ treatment has been attributed to its antiangiogenic activity. Indeed, immunocytochemical analyses showed a reduced VEGF expression in mice treated with BE- $\gamma$-cyclodextrin derivative (GCDG) complex in comparison with the control group [39]. The molecular basis of $\mathrm{BE}$ antimigration and antiangiogenic activities remains to be determined.

\section{Potential Mechanisms of BE-Mediated Anticancer Activity}

A rapidly rising number of studies have shown that the induction of apoptotic cell death is an essential mechanism of anticancer agents activity [47-49], including BE. It has been demonstrated that disruption of the apoptosis machinery is a typical feature of tumour cells [50-52]. Apoptosis is a type of programmed cell death, characterized by a series of complex, specific biochemical and cytomorphological events. Two main pathways of apoptosis have been identified, the extrinsic (death receptor-related) and the intrinsic (mitochondriondependent). The extrinsic pathway is initiated by external signals, for instance, the binding of molecules (ligands), such as Fas, TNF, or TRAIL, to their respective death receptors, localized in the cell surface. The intrinsic apoptosis pathway is activated by different stimuli, such as DNA damages, oxidative stress, radiation, and growth factors withdrawal [53].

An ability to trigger apoptosis in tumour cells has been proved as one of mechanisms underlying BE cytotoxicity and its antiproliferative potential. BE treatment has resulted in cytomorphological alterations characteristic for cells undergoing apoptosis, like cell rounding, chromatin condensation, nuclear fragmentation, membrane blebbing, and formation of apoptotic bodies [26]. Likewise, inhibition of HeLa cells proliferation has been accompanied by morphological changes, characteristic of apoptosis: cells have become smaller and the morphology has showed karyopycnosis, when exposed to BE for $24 \mathrm{~h}$, and the effect was a dose-dependent [24]. BE treatment of murine melanoma cells B164A5 has demonstrated almost equal amounts of apoptotic and dead (necrotic) cells [39]. BE has been shown to induce apoptotic cell death in human lung adenocarcinoma cells in vitro (A549 cell line). The amount of apoptotic cells has significantly increased by $27.64 \%$ in comparison with control, untreated cells [29]. BE has been shown to increase substantially the number of cytosolic oligonucleosomal fragments in A549 cell line [23]. More detailed studies have shown that BE induces apoptosis of human cancer cells through the mitochondrial (intrinsic) pathway in A549, Jurkat [54] and HeLa cancer cell lines [26, 54]. $\mathrm{BE}$ proapoptotic activity in HeLa cells has involved the sequential activation of caspases 9, 3, and 7 and the cleavage of poly (ADP-ribose) polymerase (PARP) [24]. The cleavage of caspase-3 substrate PARP to the $85 \mathrm{kDa}$ form of the protein has been observed, which points at a caspase-activated apoptotic cell death. The activity of caspase- 8 remained unchanged, suggesting a lack of extrinsic pathway activation, while caspase- 9 has been shown to be initially activated, followed by cytochrome $\mathrm{c} / \mathrm{Smac}$ proteins release from the mitochondrial intermembrane space, mitochondrial membrane potential depolarization, and rapid translocation to the mitochondrion of Bax and Bak proteins (proapoptotic members of the Bcl-2 family) [26]. In another study, BE had no influence on the total expression of Bax and Bcl-2, on mRNA as well as on protein level, and the total expression of Bak protein in HT-29 cancer cells [23]. However, a few reports have demonstrated that $\mathrm{BE}$ treatment induced the expression of other cellular proteins indirectly involved in apoptosis. By means of pharmacoproteomic approach, BE has been shown to upregulate aconitate hydratase and malate dehydrogenase in cancer cells, enzymes involved in ATP generation, supporting the involvement of mitochondrial pathway as the main mechanisms of BE-induced apoptotic cell death [29]. BE-mediated downregulation of isoform 1 of 3-hydroxyacyl-CoA dehydrogenase type 2, also known as enoyl-CoA hydratase, an enzyme related to lipid metabolism, should be further investigated to elucidate its involvement in $\mathrm{BE}$-induced apoptosis. BE treatment resulted also in decrease of poly ( $\mathrm{rC}$ )-binding protein 1 expression. The poly ( $\mathrm{rC}$ )binding protein 1 was reported to protect cells from different apoptosis inducers and modulate heat shock protein 90- $\alpha 2$ 
(HSP90- $\alpha$ 2) expression, which is involved in the regulation of mitochondrial membrane permeabilization and cytochrome $\mathrm{c}$ release. This might be a mechanism by which $\mathrm{BE}$ sensitises cancer cells to undergo apoptosis. Moreover, a highly purified TE from Betulae cortex, containing BE as a main component, displays a dose-dependent proapoptotic effects on HaCaT and A431 cells, similar to its main constituents, BE and BA [44].

Apoptosis induction is often a consequence of cell cycle disturbances. The cell cycle progression is controlled by cyclins, which are a regulatory proteins family of cell cycledependent kinases (CDKs) [55]. Regulation of the cell cycle has become a challenge and a promising target for cancer therapy [56]. Thus, numerous anticancer agents have been reported to arrest cell cycle at the $G_{0} / G_{1}, S$, or $G_{2} / M$ phases and consequently trigger apoptosis of cancer cells [57-60].

Surprisingly, limited attention has been given to the regulation of cell cycle by $\mathrm{BE}$ in cancer cells. $\mathrm{BE}$ at a concentration $10 \mu \mathrm{M}$ has been shown to induce an arrest of murine melanoma B164A5 cells in $S$ phase, with a concomitant decrease in the number of cells in the $G_{0} / G_{1}$ phases [39]. $\mathrm{BE}$ treatment of HepG2 cells (hepatoma) induced a late stage $\mathrm{G}_{0} / \mathrm{G}_{1}$ phase cell cycle arrest, and at the early stage $S$ phase, and a subsequent decrease in the amount of cells in the $G_{2} / M$ phases at a relatively low concentration $(11.29 \mu \mathrm{M} / 5 \mu \mathrm{g} / \mathrm{mL})$. Another study, using hepatoma Hep3B cells, has shown that BE treatment resulted in a cell cycle arrest at the $G_{2} / M$ phase, showing different effects of $\mathrm{BE}$ in regulation of the cell cycle, depending on hepatoma cells type. Furthermore, BE has been reported to slightly reduce DNA replication, without influencing the expression level of cell cycle regulatory genes, p21 and p53 in hepatoma cells [61]. p21 and p53 expression level were also not affected after BE treatment in other tumor cell lines originating from central nervous system (medulloblastoma/rhabdomyosarcoma, neuroblastoma, and glioma) and various peripheral cancers including lung, colon, thyroid, breast, leukaemia, multiple myeloma, and several tumour primary cultures [23].

Cell division perturbations after BE treatment could be linked to direct interactions with DNA topoisomerases (Topo), but not with DNA, at concentrations comparable with those of the well-known inhibitor etoposide. BE, among other lupane- and oleanane-type triterpenoids from the bark of Phyllanthus flexuosus, has been reported to selectively inhibit the activity of human Topo II in a dose-dependent manner. Topo are known to play an essential role in DNA metabolism, affecting replication, transcription, recombination, and mitotic chromosome segregation [62]. Thereby, Topo might be a target for the antitumour activity of BE. Topo I inhibitors are known to induce apoptosis in cancer cells $[63,64]$. Whereas BE affects Topo II activity, it has no influence on the activity of human Topo I [25].

Another enzyme involved in cell division and affected by $\mathrm{BE}$ treatment $\left(\mathrm{IC}_{50} 20 \mu \mathrm{M}\right.$ ) is cAK (cyclic AMP-dependent protein kinase) which is activated by a plethora of extraand intracellular signals. A central network player, cAK, is involved in the regulation of a variety of cellular processes including metabolism, cell division, specific gene expression, and development [65]. The inhibition of cAK by BE is specific as no changes in the activity of ERK1/2 and AKT kinases were observed [23]; the two latter kinases are frequently pathologically hyper-activated in several human cancers $[66$, 67].

$\mathrm{BE}$ has been searched for its effect on human melanocortin (MC) receptor signalling pathway. Human $\mathrm{MC}$ receptors-expressing COS-7 cells bind $\mathrm{BE}$ with different specificities depending on the MC subtype. The affinity of $\mathrm{BE}$ to the MCRs is MC1 $>\mathrm{MC} 3>\mathrm{MC} 5>\mathrm{MC} 4$. Furthermore, $\mathrm{BE}$ antagonizes $\alpha$-melanocyte-stimulating hormone- ( $\alpha$-MSH-) induced accumulation of cAMP to some extent in the mouse melanoma cell line B16-F1, which naturally expresses $\mathrm{MCl}$ receptor without stimulating MC receptor-associated generation of cAMP [68]. $\mathrm{MCl}$ receptor subtype is expressed almost in each cutaneous cell type, in immune and in melanoma cells $[69,70]$. It is also worth mentioning that the $\mathrm{MC} 1$ receptor has been suggested to be a crucial modulator of epidermal melanocyte proliferation and differentiation $[71,72]$ and has been suggested as an important target of the antimelanoma activity of $\mathrm{BE}$ and its structurally similar substances, such as BA [68].

\section{Inhibition of Carcinogenesis and Antimutagenic Activity In Vivo}

$\mathrm{BE}$ has been confirmed as a potent antimutagenic agent of skin carcinogenesis. The topical formulation with $\mathrm{BE}$ nanoemulsion has been tested on C57BL/6J type mouse skin, chemically damaged by DMBA (7,12dimethylbenz $[\alpha]$ anthracene) as a tumour initiator and 12-O-tetradecanoylphorbol-13-acetate (TPA) as tumour promoter. Potentially, any damage of the skin surface might lead to significant pathologies, such as skin neoplasms. Observations of cutaneous damages have revealed the activity of $\mathrm{BE}$ in reducing skin lesions and irritation by considerably decreasing erythema [73]. Topical application of BE has exhibited distant effects and influenced the respiratory function of isolated liver mitochondria in a two-stage model of skin carcinoma induced in mice. The improvement of liver mitochondrial respiration and increased basal (LEAK state) and active (OXPHOS state) respiration has been observed. Moreover, BE may also influence the penetration of carcinogens and reduce damage in main organs, such as liver, since application of carcinogens on the skin surface, because of their slow penetration, leads to toxic effects especially on liver. BE has also been shown to inhibit apparition and promotion of skin tumours [46]. Similarly, birch bark dry extract (BDE, with $\mathrm{BE}$ as a main component-at least $70 \%)$ has been applied on mice with chemically-induced mutagenesis. The administration of 150 and $1500 \mathrm{mg} / \mathrm{kg}$ $\mathrm{BDE}$ to mice resulted in no mutagenic and comutagenic effects. The number of cells with chromosomal aberrations was comparable between control and BDE-treated animals. Furthermore, BDE in doses of 50, 150, and $450 \mathrm{mg} / \mathrm{kg}$ notably reduced the cytogenetic effect of mutagens, dioxidine (1,4-di$\mathrm{N}$-oxide of 2,3-bis-(hydroxymethyl) quinoxaline, DN) and cyclophosphamide ( $\mathrm{N}^{\prime}$-bis-(b-chloroethyl)- $\mathrm{N}^{\prime}$-O-trimethyl 
ester of phosphoric acid diamine, $\mathrm{CP}$ ). A single treatment with $\mathrm{BDE}$ in doses of 50 and $150 \mathrm{mg} / \mathrm{kg}$ results in approximately the same antimutagenic effect and decreased the damaging activity of DN and CP by $53-60 \%$ and $60 \%$, respectively. $\mathrm{BDE}$ inhibits free radical oxidation and thus the prooxidant mutagenic activity of $\mathrm{DN}$. The protective activity of BDE has been potentially mediated by various mechanisms, for instance, via inhibition of cytochromes P450, playing a crucial role in the metabolism of CP, or by stimulation of production of interferons, which may improve DNA repair [74].

\section{Potential Application in Therapy}

No typical clinical trials have been published using BE for the treatment of human cancer so far [12]. Nevertheless, a nonrandomized pilot study, using a birch bark extract to treat actinic keratoses (AK) $[75,76]$, suggests a preventive and therapeutic potency of $\mathrm{BE}$ in skin pathologies supporting by encouraging in vivo studies [73]. AK is considered to represent an early and noninvasive squamous cell carcinoma in situ, due to histological similarity [77], and as commonly diagnosed skin damage induced by ultraviolet light should be treated to avoid the development of nonmelanoma skin cancers [78]. A birch bark ointment (containing around 87\% of the triterpenes with predominant content of $\mathrm{BE}, 80 \%$ ), used as monotherapy for the treatment of AK, resulted in a remission of more than $75 \%$ of the lesions in $79 \%$ of the patients after treatment as a product that has been approved for use as a cosmetic in Germany [75]. Furthermore, recent tests with water-free BE-based oleogel containing a higher extract concentration have confirmed the effectiveness of the BE-based strategy in the therapy of AK. The treatment resulted in complete clearing of the lesions in $64 \%$ and partial remission (more than $75 \%$ of lesions) in $86 \%$ of the patients, after a three-month treatment period, comparably to standard therapy (cryotherapy) [76]. Additionally, a synergistic effect by the combination of $\mathrm{BE}$ and cryotherapy has been reported with no observable undesirable effects [75]. Besides, BE-based oleogel decreased the degree of epidermal dysplasia and number of dyskeratoses in treated patients during a prospective, randomized, and comparative clinical phase $2 \mathrm{a}$ study. Excellent skin tolerance for oleogel prepared from a standardized triterpene dry birch bark extract was also noticed [76]. For that reason, the treatment with birch bark ointment or BE-based oleogel is regarded as a new topical alternative for current AK therapy and a promising chemopreventive agent, especially that the risk of AK progression to invasive type of squamous cell carcinoma has been estimated between $1 \%$ and $16 \%$ [79].

In animal models and pilot studies with BE, BE-based oleogel, or triterpene birch bark extract, no severe adverse effects have been observed. BE, likewise other pentacyclic triterpenes, has also shown no toxicity. Daily administration of $\mathrm{BE}$ (doses at $540 \mathrm{mg} / \mathrm{kg}$ of body weight i.p. in rats and $300 \mathrm{mg} / \mathrm{kg}$ s.c. in dogs) resulted in very low toxicity, if any [42]. Thereby, it seems that triterpene birch bark extract and its representative compound, $\mathrm{BE}$, are safe to use in vivo.

\section{Concluding Remarks}

An increasing number of studies support the antineoplastic activity of BE. A limitation for TE's biological and pharmacological effectiveness is their poor solubility. The solution could be a complexation with hydrophilic carriers. Indeed, BE hydrosolubility can be significantly improved by highly hydrophilic semisynthetic $\beta$-cyclodextrin [80], and $\gamma$ cyclodextrin derivatives [39] as carriers, which has enhanced antiproliferative potential of BE towards cancer cell lines [80], and by incorporation in nanoemulsion [46], which may increase its bioavailability and consequently improve its activity in vitro and in vivo. Chemically synthesized cyclodextrin derivatives offer the prospect of preparation highly stable complexes with both $\mathrm{BE}$ and other terpenes, such as BA [81], and possibly might be submitted for clinical trials soon. Likewise, application of cholesterol containing BE-liposomes may be considered as a promising method to facilitate the use of $\mathrm{BE}$ in the context of anticancer therapy [54].

Due to the multitarget activity of BE on cancer cells, it may be used in combination with commonly used chemotherapeutic drugs, as their synergistic effect can help to eliminate cancer cells, including drug-resistant cells [36]. Another novel approach for the application of BE in cancer therapy may be its chemical modification with various ligands which allows obtaining an enhanced cytotoxicity towards tumour cells, better solubility, and bioavailability than the parental compound [33]. Therefore, BE has been attempted to be used as a precursor in the synthesis of novel $\mathrm{BE}$ derivatives with improved anticancer and pharmacokinetic properties.

Many of the molecular mechanisms of action of TE are still elusive which limits our understanding of this potentially beneficial group of natural compounds.

\section{Conflict of Interests}

The authors declare that there is no conflict of interests regarding the publication of this paper.

\section{References}

[1] J. Ferlay, H.-R. Shin, F. Bray, D. Forman, C. Mathers, and D. M. Parkin, "Estimates of worldwide burden of cancer in 2008: GLOBOCAN 2008," International Journal of Cancer, vol. 127, no. 12, pp. 2893-2917, 2010.

[2] A. Jemal, M. M. Center, C. DeSantis, and E. M. Ward, "Global patterns of cancer incidence and mortality rates and trends," Cancer Epidemiology Biomarkers and Prevention, vol. 19, no. 8, pp. 1893-1907, 2010.

[3] A. Jemal, F. Bray, M. M. Center, J. Ferlay, E. Ward, and D. Forman, "Global cancer statistics," CA Cancer Journal for Clinicians, vol. 61, no. 2, pp. 69-90, 2011.

[4] B. Joseph, P. Marchetti, P. Formstecher, G. Kroemer, R. Lewensohn, and B. Zhivotovsky, "Mitochondrial dysfunction is an essential step for killing of non-small cell lung carcinomas resistant to conventional treatment," Oncogene, vol. 21, no. 1, pp. 65-77, 2002. 
[5] D. J. Newman, G. M. Cragg, and K. M. Snader, "The influence of natural products upon drug discovery," Natural Product Reports, vol. 17, no. 3, pp. 215-234, 2000.

[6] J. D. McChesney, S. K. Venkataraman, and J. T. Henri, "Plant natural products: Back to the future or into extinction?" Phytochemistry, vol. 68, no. 14, pp. 2015-2022, 2007.

[7] D. J. Newman and G. M. Cragg, "Natural products as sources of new drugs over the last 25 years," Journal of Natural Products, vol. 70, no. 3, pp. 461-477, 2007.

[8] N. H. Oberlies and D. J. Kroll, "Camptothecin and taxol: historic achievements in natural products research," Journal of Natural Products, vol. 67, no. 2, pp. 129-135, 2004.

[9] R. van der Heijden, D. I. Jacobs, W. Snoeijer, D. Hallard, and R. Verpoorte, "The Catharanthus alkaloids: pharmacognosy and biotechnology," Current Medicinal Chemistry, vol. 11, no. 5, pp. 607-628, 2004.

[10] F. Bouvier, A. Rahier, and B. Camara, "Biogenesis, molecular regulation and function of plant isoprenoids," Progress in Lipid Research, vol. 44, no. 6, pp. 357-429, 2005.

[11] S. Alakurtti, T. Mäkelä, S. Koskimies, and J. Yli-Kauhaluoma, "Pharmacological properties of the ubiquitous natural product betulin," European Journal of Pharmaceutical Sciences, vol. 29, no. 1, pp. 1-13, 2006.

[12] M. N. Laszczyk, "Pentacyclic triterpenes of the lupane, oleanane and ursane group as tools in cancer therapy," Planta Medica, vol. 75, no. 15, pp. 1549-1560, 2009.

[13] M. Drag-Zalesinska, J. Kulbacka, J. Saczko et al., "Esters of betulin and betulinic acid with amino acids have improved water solubility and are selectively cytotoxic toward cancer cells," Bioorganic and Medicinal Chemistry Letters, vol. 19, no. 16, pp. 4814-4817, 2009.

[14] J. Patočka, "Biologically active pentacyclic triterpenes and their current medicine signification," Journal of Applied Biomedicine, vol. 10, no. 3, pp. 7-12, 2012.

[15] R. Ekman, "The submarin monomers and triterpenoids from the outer bark of betula verrucosa EHRH," Holzforschung, vol. 37, no. 4, pp. 205-211, 1983.

[16] C. M. Şoica, C. A. Dehelean, C. Peev et al., "Physico-chemical comparison of betulinic acid, betulin and birch bark extract and in vitro investigation of their cytotoxic effects towards skin epidermoid carcinoma (A431), breast carcinoma (MCF7) and cervix adenocarcinoma (HeLa) cell lines," Natural Product Research, vol. 26, no. 10, pp. 968-974, 2012.

[17] P. N. Diouf, T. Stevanovic, and Y. Boutin, “The effect of extraction process on polyphenol content, triterpene composition and bioactivity of yellow birch (Betula alleghaniensis Britton) extracts," Industrial Crops and Products, vol. 30, no. 2, pp. 297303, 2009.

[18] H. Gao, L. Wu, M. Kuroyanagi et al., "Antitumor-promoting constituents from Chaenomeles sinensis KOEHNE and their activities in JB6 mouse epidermal cells," Chemical and Pharmaceutical Bulletin, vol. 51, no. 11, pp. 1318-1321, 2003.

[19] B. Y. Hwang, H.-B. Chai, L. B. S. Kardono et al., "Cytotoxic triterpenes from the twigs of Celtis philippinensis," Phytochemistry, vol. 62, no. 2, pp. 197-201, 2003.

[20] M. Liu, S. Yeng, L. Jin, D. Hu, Z. Wu, and S. Yang, "Chemical constituents of the ethyl acetate extract of belamcanda chinensis (L.) DC roots and their antitumor activities," Molecules, vol. 17, no. 5, pp. 6156-6169, 2012.

[21] V. S. Prakash Chaturvedula, J. K. Schilling, R. K. Johnson, and D. G. I. Kingston, "New cytotoxic lupane triterpenoids from the twigs of Coussarea paniculata," Journal of Natural Products, vol. 66, no. 3, pp. 419-422, 2003.

[22] S. Yang, M. Liu, N. Liang, Q. Zhao, Y. Zhang, and W. Xue, "Discovery and antitumor activities of constituents from Cyrtomium fortumei (J.) Smith rhizomes," Chemistry Central Journal, vol. 7, no. 1, article 24, 2013.

[23] W. Rzeski, A. Stepulak, M. Szymański et al., "Betulin elicits anticancer effects in tumour primary cultures and cell lines in vitro," Basic and Clinical Pharmacology and Toxicology, vol. 105, no. 6, pp. 425-432, 2009.

[24] D.-Y. Wang, J. Liu, M.-Z. Yin et al., "Betulin induces apoptosis of HeLa cell lines in vitro and its possible mechanism," Tumor, vol. 32, no. 4, pp. 234-238, 2012.

[25] K. Hata, K. Hori, H. Ogasawara, and S. Takahashi, "Antileukemia activities of Lup-28-al-20(29)-en-3-one, a lupane triterpene," Toxicology Letters, vol. 143, no. 1, pp. 1-7, 2003.

[26] Y. Li, K. He, Y. Huang et al., "Betulin induces mitochondrial cytochrome $\mathrm{c}$ release associated apoptosis in human cancer cells," Molecular Carcinogenesis, vol. 49, no. 7, pp. 630-640, 2010.

[27] C. Gauthier, J. Legault, M. Lebrun, P. Dufour, and A. Pichette, "Glycosidation of lupane-type triterpenoids as potent in vitro cytotoxic agents," Bioorganic and Medicinal Chemistry, vol. 14, no. 19, pp. 6713-6725, 2006.

[28] C. Gauthier, J. Legault, S. Lavoie, S. Rondeau, S. Tremblay, and A. Pichette, "Synthesis and cytotoxicity of bidesmosidic betulin and betulinic acid saponins," Journal of Natural Products, vol. 72, no. 1, pp. 72-81, 2009.

[29] S. P. Jae, H. R. Si, K. K. Dae et al., "Anti-cancer effect of betulin on a human lung cancer cell line: a pharmacoproteomic approach using 2 D SDS PAGE coupled with nano-HPLC tandem mass spectrometry," Planta Medica, vol. 75, no. 2, pp. 127-131, 2009.

[30] S. Pacifico, M. Gallicchio, A. Fiorentino, A. Fischer, U. Meyer, and F. C. Stintzing, "Antioxidant properties and cytotoxic effects on human cancer cell lines of aqueous fermented and lipophilic quince (Cydonia oblonga Mill.) preparations," Food and Chemical Toxicology, vol. 50, no. 11, pp. 4130-4135, 2012.

[31] C. Mutai, D. Abatis, C. Vagias, D. Moreau, C. Roussakis, and V. Roussis, "Cytotoxic lupane-type triterpenoids from Acacia mellifera," Phytochemistry, vol. 65, no. 8, pp. 1159-1164, 2004.

[32] C. A. Dehelean, S. Feflea, J. Molnár, I. Zupko, and C. Soica, "Betulin as an antitumor agent tested in vitro on A431, HeLa and MCF7, and as an angiogenic inhibitor in vivo in the CAM assay," Natural Product Communications, vol. 7, no. 8, pp. 981985, 2012.

[33] S. Boryczka, E. Bebenek, J. Wietrzyk et al., "Synthesis, structure and cytotoxic activity of new acetylenic derivatives of betulin," Molecules, vol. 18, no. 4, pp. 4526-4543, 2013.

[34] V. Amico, V. Barresi, D. Condorelli, C. Spatafora, and C. Tringali, "Antiproliferative terpenoids from almond hulls (Prunus dulcis): identification and structure-activity relationships," Journal of Agricultural and Food Chemistry, vol. 54, no. 3, pp. 810-814, 2006.

[35] J. Sarek, M. Kvasnica, M. Urban, J. Klinot, and M. Hajduch, "Correlation of cytotoxic activity of betulinines and their hydroxy analogues," Bioorganic and Medicinal Chemistry Letters, vol. 15, no. 19, pp. 4196-4200, 2005.

[36] M. Drag, P. Surowiak, D.-Z. Malgorzata, M. Dietel, H. Lage, and J. Oleksyszyn, "Comparision of the cytotoxic effects of birch bark extract, betulin and betulinic acid towards human gastric carcinoma and pancreatic carcinoma drug-sensitive and drugresistant cell lines," Molecules, vol. 14, no. 4, pp. 1639-1651, 2009. 
[37] K. Hata, K. Hori, and S. Takahashi, "Differentiation- and apoptosis-inducing activities by pentacyclic triterpenes on a mouse melanoma cell line," Journal of Natural Products, vol. 65, no. 5, pp. 645-648, 2002.

[38] D. S. H. L. Kim, J. M. Pezzuto, and E. Pisha, "Synthesis of betulinic acid derivatives with activity against human melanoma," Bioorganic \& Medicinal Chemistry Letters, vol. 8, no. 13, pp. 1707-1712, 1998.

[39] C. Şoica, C. Dehelean, C. Danciu et al., "Betulin complex in $\gamma$ cyclodextrin derivatives: properties and antineoplasic activities in in vitro and in vivo tumor models," International Journal of Molecular Sciences, vol. 13, no. 11, pp. 14992-15011, 2012.

[40] M. Urban, J. Sarek, M. Kvasnica, I. Tislerova, and M. Hajduch, "triterpenoid pyrazines and benzopyrazines with cytotoxic activity," Journal of Natural Products, vol. 70, no. 4, pp. 526-532, 2007.

[41] M. Urban, M. Vlk, P. Dzubak, M. Hajduch, and J. Sarek, "Cytotoxic heterocyclic triterpenoids derived from betulin and betulinic acid," Bioorganic and Medicinal Chemistry, vol. 20, no. 11, pp. 3666-3674, 2012.

[42] S. Jäger, M. N. Laszczyk, and A. Scheffler, "A preliminary pharmacokinetic study of betulin, the main pentacyclic triterpene from extract of outer bark of birch (Betulae alba cortex)," Molecules, vol. 13, no. 12, pp. 3224-3235, 2008.

[43] C. A. Dehelean, C. Şoica, I. Ledeţi et al., "Study of the betulin enriched birch bark extracts effects on human carcinoma cells and ear inflammation," Chemistry Central Journal, vol. 6, no. 1, article 137, 2012.

[44] M. Laszczyk, S. Jäger, B. Simon-Haarhaus, A. Scheffler, and C. M. Schempp, "Physical, chemical and pharmacological characterization of a new oleogel-forming triterpene extract from the outer bark of birch (Betulae cortex)," Planta Medica, vol. 72, no. 15, pp. 1389-1395, 2006.

[45] P. A. Krasutsky, "Birch bark research and development," Natural Product Reports, vol. 23, no. 6, pp. 919-942, 2006.

[46] C. A. Dehelean, S. Feflea, D. Gheorgheosu et al., "Antiangiogenic and anti-cancer evaluation of betulin nanoemulsion in chicken chorioallantoic membrane and skin carcinoma in Balb/c mice," Journal of Biomedical Nanotechnology, vol. 9, no. 4, pp. 577-589, 2013.

[47] M. Brown and L. D. Attardi, "The role of apoptosis in cancer development and treatment response," Nature Reviews Cancer, vol. 5, no. 3, pp. 231-237, 2005.

[48] S. Fulda and K. M. Debatin, "Extrinsic versus intrinsic apoptosis pathways in anticancer chemotherapy," Oncogene, vol. 25, no. 34, pp. 4798-4811, 2006.

[49] S. Elmore, "Apoptosis: a review of programmed cell death," Toxicologic Pathology, vol. 35, no. 4, pp. 495-516, 2007.

[50] G. Del Poeta, A. Bruno, M. I. Del Principe et al., "Deregulation of the mitochondrial apoptotic machinery and development of molecular targeted drugs in acute myeloid leukemia," Current Cancer Drug Targets, vol. 8, no. 3, pp. 207-222, 2008.

[51] J. Plati, O. Bucur, and R. Khosravi-Far, "Dysregulation of apoptotic signaling in cancer: molecular mechanisms and therapeutic opportunities," Journal of Cellular Biochemistry, vol. 104, no. 4, pp. 1124-1149, 2008.

[52] I. N. Lavrik, "Regulation of death receptor-induced apoptosis induced via CD95/FAS and other death receptors," Molekuliarnaia Biologiia, vol. 45, no. 1, pp. 173-179, 2011.

[53] D. R. Green, R. A. Knight, G. Melino, A. Finazzi-Agro, and S. Orrenius, "Ten years of publication in cell death," Cell Death and Differentiation, vol. 11, no. 1, pp. 2-3, 2004.
[54] F. B. Mullauer, J. H. Kessler, and J. P. Medema, "Betulin is a potent anti-tumor agent that is enhanced-by cholesterol," PLoS ONE, vol. 4, no. 4, article el, Article ID e5361, 2009.

[55] C. J. Sherr, "The pezcoller lecture: cancer cell cycles revisited," Cancer Research, vol. 60, no. 14, pp. 3689-3695, 2000.

[56] G. K. Schwartz and M. A. Shah, "Targeting the cell cycle: a new approach to cancer therapy," Journal of Clinical Oncology, vol. 23, no. 36, pp. 9408-9421, 2005.

[57] H. Harada, U. Yamashita, H. Kurihara, E. Fukushi, J. Kawabata, and Y. Kamei, "Antitumor activity of palmitic acid found as a selective cytotoxic substance in a marine red alga," Anticancer Research, vol. 22, no. 5, pp. 2587-2590, 2002.

[58] Y.-L. Cheng, W.-L. Chang, S.-C. Lee et al., "Acetone extract of Angelica sinensis inhibits proliferation of human cancer cells via inducing cell cycle arrest and apoptosis," Life Sciences, vol. 75, no. 13, pp. 1579-1594, 2004.

[59] J. Sun and R. Hai Liu, "Cranberry phytochemical extracts induce cell cycle arrest and apoptosis in human MCF-7 breast cancer cells," Cancer Letters, vol. 241, no. 1, pp. 124-134, 2006.

[60] X. Hu, X. Zhang, S. Qiu, D. Yu, and S. Lin, "Salidroside induces cell-cycle arrest and apoptosis in human breast cancer cells," Biochemical and Biophysical Research Communications, vol. 398, no. 1, pp. 62-67, 2010.

[61] S. H. Oh, J. E. Choi, and S. C. Lim, "Protection of betulin against cadmium-induced apoptosis in hepatoma cells," Toxicology, vol. 220 , no. 1, pp. 1-12, 2006.

[62] S.-I. Wada, A. Iida, and R. Tanaka, "Screening of triterpenoids isolated from Phyllanthus flexuosus for DNA topoisomerase inhibitory activity," Journal of Natural Products, vol. 64, no. 12, pp. 1545-1547, 2001.

[63] S. Simizu, M. Takada, K. Umezawa, and M. Imoto, "Requirement of caspase-3(-like) protease-mediated hydrogen peroxide production for apoptosis induced by various anticancer drugs," The Journal of Biological Chemistry, vol. 273, no. 41, pp. 26900 26907, 1998.

[64] D. E. Wood and E. W. Newcomb, "Caspase-dependent activation of calpain during drug-induced apoptosis," The Journal of Biological Chemistry, vol. 274, no. 12, pp. 8309-8315, 1999.

[65] B. H. Wang and G. M. Polya, "Selective inhibition of cyclic AMP-dependent protein kinase by amphiphilic triterpenoids and related compounds," Phytochemistry, vol. 41, no. 1, pp. 5563, 1996.

[66] E. Tokunaga, E. Oki, A. Egashira et al., "Deregulation of the akt pathway in human cancer," Current Cancer Drug Targets, vol. 8, no. 1, pp. 27-36, 2008.

[67] P. J. Roberts and C. J. Der, "Targeting the Raf-MEK-ERK mitogen-activated protein kinase cascade for the treatment of cancer," Oncogene, vol. 26, no. 22, pp. 3291-3310, 2007.

[68] R. Muceniece, K. Saleniece, U. Riekstina, L. Krigere, G. Tirzitis, and J. Ancans, "Betulin binds to melanocortin receptors and antagonizes $\alpha$-melanocyte stimulating hormone induced cAMP generation in mouse melanoma cells," Cell Biochemistry and Function, vol. 25, no. 5, pp. 591-596, 2007.

[69] Y. Xia, R. Muceniece, and J. E. S. Wikberg, "Immunological localisation of melanocortin 1 receptor on the cell surface of WM266-4 human melanoma cells," Cancer Letters, vol. 98, no. 2, pp. 157-162, 1996.

[70] V. Chhajlani, "Distribution of cDNA for melanocortin receptor subtypes in human tissues," Biochemistry and Molecular Biology International, vol. 38, no. 1, pp. 73-80, 1996. 
[71] J. E. S. Wikberg, R. Muceniece, I. Mandrika et al., "New aspects on the melanocortins and their receptors," Pharmacological Research, vol. 42, no. 5, pp. 393-420, 2000.

[72] A. Catania, S. Gatti, G. Colombo, and J. M. Lipton, “Targeting melanocortin receptors as a novel strategy to control inflammation," Pharmacological Reviews, vol. 56, no. 1, pp. 1-29, 2004.

[73] S. A. Ciurlea, C. Tiulea, E. Csanyi et al., "A pharmacotoxicological evaluation of a betulin topical formulation tested on C57BL/6J mouse experimental nevi and skin lesions," Studia Universitatis Vasile Goldis Arad, Seria Stiintele Vietii, vol. 20, no. 4, pp. 5-9, 2010.

[74] A. K. Zhanataev, G. A. Presnova, A. N. Chistyakov, and A. D. Durnev, "Effect of Betula bark extract on spontaneous and induced mutagenesis in mice," Bulletin of Experimental Biology and Medicine, vol. 138, no. 5, pp. 475-478, 2004.

[75] C. Huyke, M. Laszczyk, A. Scheffler, R. Ernst, and C. M. Schempp, "Treatment of actinic keratoses with birch bark extract: a pilot study," JDDG: Journal der Deutschen Dermatologischen Gesellschaft, vol. 4, no. 2, pp. 132-136, 2006.

[76] C. Huyke, J. Reuter, M. Rödig et al., “Treatment of actinic keratoses with a novel betulin-based oleogel. A prospective, randomized, comparative pilot study," Journal of the German Society of Dermatology, vol. 7, no. 2, pp. 128-134, 2009.

[77] W. Fu and C. J. Cocherell, "The actinic (solar) keratosis: a 21stcentury perspective," Archives of Dermatology, vol. 139, no. 1, pp. 66-70, 2003.

[78] R. I. Ceilley and J. L. Jorizzo, "Current issues in the management of actinic keratosis," Journal of the American Academy of Dermatology, vol. 68, no. 1, supplement 1, pp. S28-S38, 2013.

[79] R. G. Glogau, "The risk of progression to invasive disease," Journal of the American Academy of Dermatology, vol. 42, no. 1, part 2, pp. S23-S24, 2000.

[80] C. M. Şoica, C. I. Peev, S. Ciurlea, R. Ambrus, and C. Dehelean, "Physico-chemical and toxicological evaluations of betulin and betulinic acid interactions with hydrophilic cyclodextrins," Farmacia, vol. 58, no. 5, pp. 611-619, 2010.

[81] H. M. Wang, C. M. Şoica, and G. Wenz, "A comparison investigation on the solubilization of betulin and betulinic acid in cyclodextrin derivatives," Natural Product Communications, vol. 7, no. 3, pp. 289-291, 2012. 

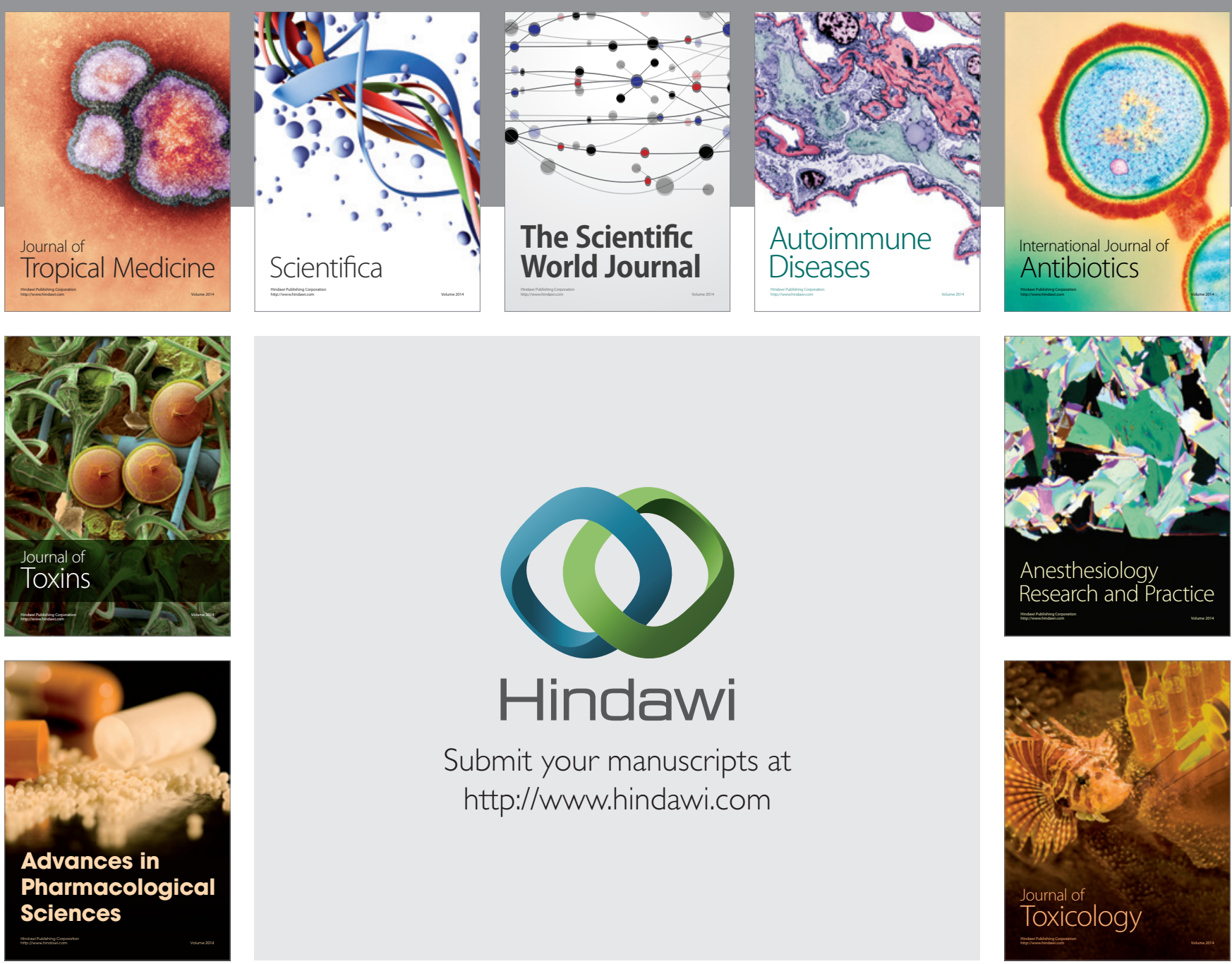

\section{Hindawi}

Submit your manuscripts at

http://www.hindawi.com
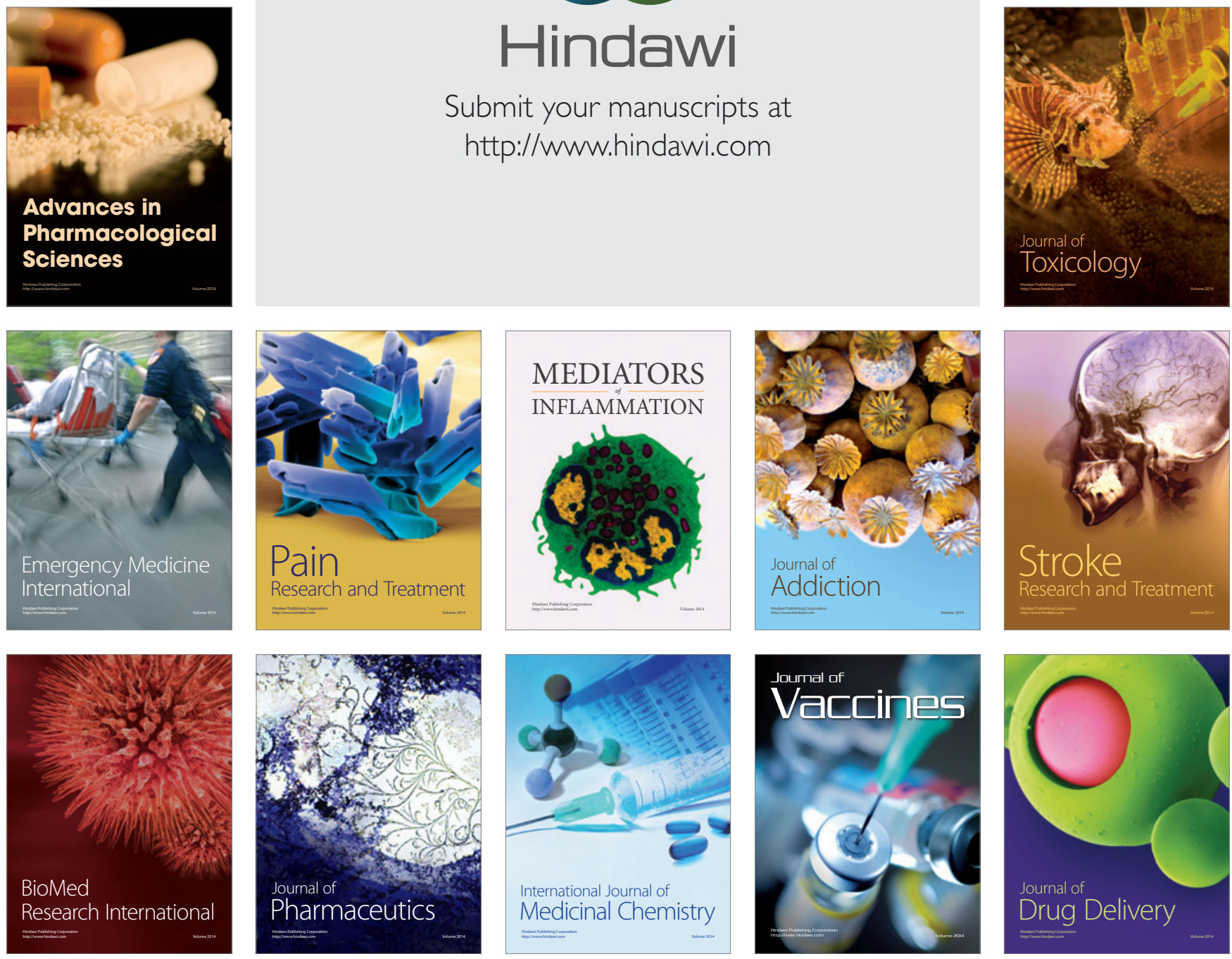